\title{
Picture books as performative texts: Or how to do things with words and pictures
}

\author{
Kerry Mallan
}

$\mathrm{T}$ he subtitle of this paper acknowledges the British philosopher J. L. Austin's influential book on speech act theory, How to do things with words (1962). Austin's work on language study marked a significant shift in linguistic philosophies by concentrating attention on what language does rather than what it $i s$, and away from language as a formal structure to language as a social process. Such understandings have resonated through critical theory and other theoretical writings of the past four decades.

This paper attempts to apply some of Austin's ideas of the performative to children's picture books. It also discusses the performative in terms of Judith Butler's notion of performativity and gender, and in relation to reader response theory. This seemingly eclectic approach to the topic suggests a certain ambitiousness and runs the risk of trying to make a neat fit from three differently constructed notions of the performative which appear, superficially at least, to have little in common. Within the scope of this essay I will not be able to do justice to any one of the three theoretical perspectives. I therefore offer the following discussion as a starting point, a conversation piece that I hope will prompt further debate and produce more sustained arguments by other writers interested in the application of critical theory to children's literature.

Children's literature, like many other linguistic performances, interacts with the conventions of social reality, invokes particular effects, and serves a socialising function. It also induces readers to participate in the imaginative construction of a fictional world. Such imaginative construction depends on reader knowledge of how language functions in a social context. In the case of picture books, the illustrations add a further dimension in that readers draw on knowledge of artistic representation and pictorial codes as part of the reading act. Consequently, picture books will be considered in terms of their linguistic and aesthetic performances, their social and cultural significance, and in relation to their (implied) users.

Austin's notion of the performative

'Performative' is Austin's term for language with the primary function of doing something. Rather than viewing language as describing some objective reality, Austin contends that the performative indicates that 'the issuing of the utterance is the performing of an action' $(1962$, p.6). While Austin originally distinguished performative from constative utterances (the latter being utterances that say rather than do something), he subsequently undermined his original proposition by claiming that 'saying' equals 'doing'. This turnaround dismisses the opposition between speech statements (constative) and speech acts (performative), contending that language both states and performs (see Petrey 1990, Chapter 2).

A key consideration of Austin's speech-act theory is that when language performs it does so within a social context and it must exist as an acceptable conventional procedure having a certain conventional effect (1962, p.14). Thus, the performative utterance will invariably be accompanied by other performed actions, either by the speaker or others. Furthermore, the words that do things are either successful or unsuccessful (Austin uses the terms 'felicitous' or 'infelicitous') in their invoking of a convention. The concept of a performative utterance being felicitous or infelicitous is tied to what Austin called illocutionan force. In the act of saying something, such as informing, warning or ordering, the speaker performs an illocutionary act. By attending to the illocutionary force of a performative utterance, Austin pays attention to language and social practice. As Petrey explains: 'To understand what words say, we can look only at the words. To understand what they do, we must also look at their users' (1990, p.15).

A further category of speech-act theory is Austin's designation of perlocutionary consequences, that is, what happens after the utterance of an illocution. A perlocutionary act brings about or achieves something by saying something, such as convincing, deterring, or surprising (Austin 1962, pp. 99-100). According to Petrey, 'Although perlocutionary events can ignore or undo as well as affirm the things done by words, the words' illocutionary status is unaffected if the convention is observed when the words are spoken' $(1990$, p.16). While Austin preferred to concentrate on the illocutionary force of the performative, he did not exclude the perlocutionary force of an illocution; to do so ignores the fact that an illocution will have consequences (intentional and unintentional), which may constitute a strategic and communicative action. The strategic action of a 
perlocutionary act will be illustrated later in the discussion with reference to Don't step on the crack! (McNaughton 2000).

While Austin focussed on speech rather than writing and claimed that the performative term was the province of 'ordinary circumstances' and does not apply to plays, poems or other literary texts, which he considered were parasitic upon the more conventional use of language (p.22), his ideas have been discussed among literary theorists, philosophers, and linguists. The appropriateness of children's literature as a context for applying Austin's speech-act theory is implied in the following statement by Petrey: 'to read a work of imaginative literature is to encounter words that do things through processes like those allowing all other performative language to produce what it names' (1990, p.10). In literary texts, the fictional characters and their fictional world reproduce conventional speech acts and performances common to the real world (we know the kinds of characters depicted, we are familiar with the conventional acts and rituals they perform, and so on). As Culler explains, like the performative, the literary utterance 'brings into being characters and their actions' (2000, p.506)

In the picture book examples that form part of the discussion, the illustrations will be considered as non-verbal acts which may also carry (like the words) an illocutionary and perlocutionary force. Furthermore, the perlocutionary force of picture books prompts a response by those who read it. To extend the application of Austin's concept of performativity to illustrations could be regarded as a misuse or mis/appropriation. However, the verbal and visual codes of picture books necessitate a widening of the application of the performative in order for us to see how visuals similarly encode and perform the narrative.

\section{Butler's notion of performativity}

In formulating her notion of gender performances, Judith Butler considers the ways in which gender identity is constructed iteratively through complex citational practices (Butler 1990; 1993). Her notion of gender as performative, in the sense that the 'acts' and 'corporeal style' that the gendered body performs, 'suggest[s] a dramatic and contingent construction of meaning' (Butler 1990, p.139). That is, these various performances of gender create the idea of gender. Thus, Butler argues that there is no core identity or essential self or category (such as 'woman' or 'man'). Rather, the self and its gender are realised only as performances. Butler's attention to the body provides a site for considering the nature of gender representation and identity in children's picture books. The visual encoding of gender in picture books may maintain the coherence of gender identity through persistent references to male/ female categories, in which each category is defined through its difference to the other. Picture books may also invite a disruption of this fixed gender representation and oppositional categorisation through different kinds of parody and other performative modes.

While Butler sees gender as a compulsory performance, and identity as 'an effect that is produced or generated' (1990, p.147), she does not dismiss the idea of agency. For Butler, agency is located in the way that variations of action, and the possibility of variation in repetition, carry meaning and create identity. Butler's idea of agency can also be realised for readers who encounter picture books which actively subvert accepted conventions and offer a different reading experience. Agency can also be seen in terms of the genre, whereby the disruption or subversion of publishing and writing norms results in a text which changes the historical and social realities of the genre and "'make[s] new" in a space of convention' (Culler 2000, p.518).

Parker and Sedgwick (1995, p.6) suggest that the two strands of performativity expressed variously through the works of Austin and Butler have a common meeting point in their interrogations of the relation of speech to act (Austin) and of act to identity (Butler). For Austin, the performative occurs in a single act, whereas for Butler the performative is a regular repetition of an act. Hence, the 'act' or the doing of something is pivotal to the two notions of the performative. Culler develops the connection further by considering the social and cultural embeddedness of the 'act'. He suggests that Butler's notion of the repeated 'acts', which one performs to become a man or a woman, resembles Austin's performative acts, in that they also 'depend on social conventions, habitual ways of doing something in a culture' (2000, p.513). Thus, the subject is created through a series of performative acts. 
While there are undoubtedly points of convergence between Austin and Butler, there is nevertheless an essential difference in their interpretation of the performative itself. It is, therefore, foolish to try to impose Austin's theorising in toto onto Butler's in an attempt to make the pieces fit. It is perhaps more productive to see how the two can be complementary, each providing a perspective that the other is unable to offer.

Reading performance and reader response theory The third strand that I want to consider is reader response. It seems a logical extension of both Austin's and Butler's theorising to consider an audience: one who is a witness to the act while engaging in the act of reading. As the child encounters the picture book text, she participates in a reading practice which, in its broadest sense, is a performance whereby she negotiates various roles of reader, spectator, witness, social commentator, art critic, co-creator, and performer. Each role has its own specific sets of acts and situated identities which mimic and repeat to some extent something heard, seen, or experienced before; hence, the iterative nature of the reading 'act'. In addition, there are the cultural and artistic conventions which permit these reader roles or states to be enacted by shaping ways of rcading pictures and constructing meaning, and prompting dramatic interpretation. In a similar vein, Smagorinsky (2001), drawing on Bakhtin, considers this cultural mediation between reader and text as one which extends beyond a dialogic relationship between reader and text, to include a broader range of texts, practices, genres, and readers.

Rather than focus solely on a reader-oriented theory, reader response (or reception theory) critics, such as Rosenblatt (1985), Iser (1978; 1989) and Jauss (1982), look to the relationship between text and reader. While there have been difficulties over the years with the interpretation and application of these theorists' works, particularly with respect to privileging the personal over the critical, the notion of reader stance (efferent and aesthetic) which Rosenblatt proposed need not strip the aesthetic of interpretive or critical possibilities. Interpretation is a social act and the transaction between reader and text involves examining the social in the text as well as considering the ways writing performs as its words act on and through the reader, coaxing a particular response or (aesthetic) stance; such is the 'shaping role of language' (Culler 2000, p.517) and its ability to fulfil a reader's desire. It is in their attention to textuality that these theorists offer a way for considering the reading act in relation to the performative.

A further point of convergence between response theory and the performative lies in the idea of intentionality. Iser (1989) contends that an intentionalist understanding of the meaning of a text is inadequate. As Culler explains:

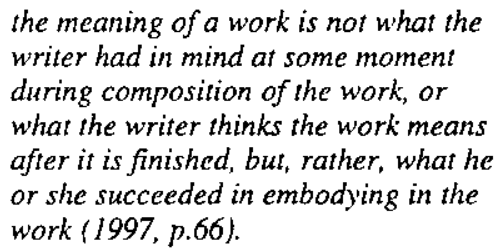

the meaning of a work is not what the writer had in mind at some moment during composition of the work, or what the writer thinks the work means after it is finished, but, rather, what he or she succeeded in embodying in the work (1997, p.66).

This view of intentionality aligns with Austin's consideration of the performative or the illocutionary act which 'is constituted not by intention' (1962, p.128), but exists through communal ratification. What words do depends not on speakers and writers, but on conventional contexts. The presence of the speaker or information about the author's intentions is an illocutionary irrelevance. Rather, it is the convention enacted by the words that matters.

Furthermore, Iser (1989) contends that a text's indeterminacy makes certain kinds of demands on readers who must bring a text to life when it is read. As Iser suggests, the gaps or indeterminate parts of a literary text are not deficiencies, but are a basic element for the aesthetic response' ( p.9). It is by attending to the verbal and visual codes in piclure books that a reader's response extends beyond basic decoding to a fuller appreciation of the text's cognitive, perceptual, and aesthetic possibilities. Readers also play a part in this indeterminacy as they bring to the text their own range of experiential knowledge, attitudes, and dispositions. Consequently, the dialectic between reader and text is complicated by the indeterminacy of both reader and text (Stephens 1992, p.59).

By considering reader-response theory, I examine the ways in which picture books invoke ways of reading the 
performative through words and pictures, and the ways in which the 'act-like' quality of the performative is realised through the body of both the represented subject and the implied reader. Intratextually, the body features in picture books through the artistic representation of fictional subjects and extratextually in the embodied presence of real readers. Notions of the body allow us to give equal treatment to both visual and verbal components of picture books in discussions of gender/ identity, performative utterances and their illocutionary and perlocutionary force, and reader response. As Butler's argument about the body contends, it is the repeated acts that constitute a performance which in turn is culturally shaped. It is also through the body that the reading subject repeatedly experiences and performs the act of reading as she draws on her knowledge of other texts (intertextuality), story conventions, cultural and social practices, personal experiences, and engages in imaginative projections. To take this line of argument means a refusal of any rationalist definition of reading as a purely cognitive process, as such a mind/body split fails to consider the ways readers think, feel, and experience through the body. It is also largely through the body (speech, actions, thoughts) that a fictional character's subjectivity is constructed. In a related sense, Smagorinsky (2001) argues that readers' subjectivity or sense of self and the world can be 'constrained' or 'unbridled' as they negotiate the cultural codes and basis of texts. Smagorinsky's claims to an 'unbridled subjectivity', however, must always be considered provisional and located in what he calls the 'transactional zone', a space where he suggests meaning is made.

The following sections of the discussion use selected picture books to illustrate the intertwining threads of performativity and reader response and are framed by three key questions: (i) How is the performative (in its various manifestations) invoked in picture books? (ii) How do context and reader disposition affect the stance that one takes in reading? and (iii) How does desire shape the performative?

\section{Performing the performative}

Kress suggests that 'Communication has always been multi-semiotic' (1997, p.60) involving multiple modes of oral, visual, written, and bodily elements. When adults read picture books to children, they often provide an embodied performance of the text. For example, they might gesture, make sound effects, use vocal intonation, insert ad lib comments. While this supplementary dispiay of language and performance is a common feature of reading practices between adults and children, children also perform and respond to the words and visuals in embodied ways-clapping, shaking their head, nodding in approval, making personal observations and so on. While we know all this through years of experience with children, we need to step back from the latent manifestations of reader response and look at the characteristics of words and illustrations in order to see how picture books incite particular kinds of responses and invoke the performative.

Perhaps we come close to claiming the performative significance of picture books when we look at the ways in which narrative, performance, text, and reader intersect. In the case of many Pamela Allen books the visuals encode a sense of performance through their fluid design. The semiotic representations of bodily acts and gestures not only lend a sense of movement to the characters, but also invite readers to perform (either imaginatively or literally)todance, march, join in the fun. The words, too, demonstrate that language (in a literary text) may also do things with a direct and perceptible impact on its characters. Consequently, in MrMcGee and the Biting Flea (1998) Mr $M c G e e$ and the dog scratch, leap, and wriggle in an attempt to be rid of the biting flea. Austin's theatrical lexiconperform and act-corresponds, in this instance, to the theatrical nature of Allen's text where characters perform their antics before a reading audience (which may be a single reader or several readers). The words and visuals together illustrate the relationship between action and language, performance and representation.

Picture books (like other texts) induce a reader to take up a position in the drama of the text and to participate in its unfolding scenes. The rhetorical force of language and illustration persuades readers to be caught up in the rhythms and rhetoric of the words and the expressive and convincing power of the visuals. In addition to such persuasive elements, words, illustrations, and possibly an adult reader encourage the child reader/listener to anticipate, speculate, and be excited by the sequential events of the story. Picture books 
imply a certain reader and through particular textual strategies such as dialogue, hooks, questions, repetition, rhyme scheme, and structure build up a pattern of expectation in that reader.

In Fowl Play'(Allen, 1996), these textual strategies achieve both comic effect and intrigue. Thereby, the 'ideal reader' has a sense of humour and a desire to be clever, a crime buster. However, in order for any reader to realise these roles, she must also be knowledgeable about language games, other texts and genres, and semiotics. In other words, she must be able to understand the ways that both the words and the visuals achieve a playfulness and a lumorous effect. While children do not know that these are the knowledge and skills needed to appreciate the text to its fullest, many are, nevertheless, knowing readers in that they have a wide experience of texts and textual play. Therefore, children gain these attributes through their engagement with print and other media.

Dialogue is a key performative effect in Fowl Play' as it constitutes action. The dialogue appears in the speech bubbles in the illustrations and as such is a continuous commentary and interchange that runs parallel to the third person narrative that is positioned above or below the illustrations. In Austin's sense, the dialogue represents 'speech acts' and is the main force of linguistic interaction in the unfolding drama. As such, dialogue is not so much descriptive (although at times it is) as performative. The dialogic form, however, does not guarantee performativity. In a comedic sense, the dialogue in Fowl Play is the main means for humour, textual play and allusion as apparent in the following excerpt when Hubert Hound, in his search for the chicken thief, questions Badger about the contents of his cupboard:

\section{Hubert Hound: 'What's in the big} cupboard then stripey?'

Badger: 'Tomorrow's dinner, that's what stumpy, look!' [When the door opens two dead chickens are shown hanging by their feet.]

$$
\begin{gathered}
\text { Badger: 'Yeah, chickens! What did } \\
\text { you expect, vegeburgers?' }
\end{gathered}
$$

This short excerpt demonstrates the illocutionary and perlocutionary effect of dialogue: Hubert Hound's demand to know the contents of the cupboard results in Badger's disclosure of its contraband contents. Whilst the dialogue veers towards the colloquial and the spontaneous retort, it nevertheless serves as a mode of action. Performance, therefore, operates through timing and repartee and is realised in the mutually constitutive moment between reader and text. Furthermore, the characters' social situation and standing become manifest in the illocutionary possibilities open to them. For instance, Badger's wisecrack does not clear him of being a suspect as his character and reputation as an opportunist have already been coloured in the initial cast list in the endpapers where he is described as 'a bad-tempered animal who is known to eat chickens if he gets the chance'. Thus, the linguistic and the extralinguistic (in terms of readers' knowledge about badgers and bad-tempered characters) constitute the social world of the text and make a connection with the social world of the reader.

The endpapers serve as both a 'rogues gallery' and a storyboard. A series of eight frames visually introduce the characters and setting, and the supplementary text describes the characters' personalities as well as sets up readers to anticipate a particular kind of story, and to rely on previous knowledge of stereotypes in order to predict the outcome. The familiar narrative strategy of the red herring lures a reader into the story and, in order to position her as a dupe, her subjectivity is, in Smagorinsky's terms, culturally constrained. For instance, the text accompanying the picture of a very worried and guilty looking fox reads: 'It looks like Foxy is well and truly to blame for the disappearing chickens'. However, for the astute reader, perhaps one versed in the ways of crime fiction, other helpful, albeit subtle, clues are available. For example, we are told that Hilda Rabbit is '... an excitable character, who doesn't seem to like foxes all that much'. The ambiguity of this statement is resolved once the reader has completed the story and knows the identity of the chicken thief. To a large extent the meanings a reader derives from Fowl Play depend on her knowledge of intertexts-crime fiction (even the title playfully evokes Agatha Christie's Murder Most Foul, though it is unlikely children would be aware of this), B grade detective movies of the 1940s, storybook 
characters and their stereotypical anthropomorphic behaviours: for example, foxes are cunning and always guilty. Consequently, this picture book relies on mimicry and iteration and the ideal reader is one who implicitly recognises these dual features.

The layout of the pages with multiple frames, the position of the framing narrative text, and the embedded speech bubbles within the illustrations are further strategies which require readers to actively engage with the events, dialogue, and running jokes of fered on the page. In focussing attention on what is going on in a scene, Allen is able to prime readers to anticipate future scenes as the pages of the picture book are turned. Readers are positioned in several ways to read and to see initially certain things and not others. For example, formal elements of the illustration (colour, placement, line, sequencing), the visual typography (bold lettering, capitals, punctuation), and the judicious partnership between narrative breaks and page layout can all position readers in particular ways. By focussing attention on certain details rather than others, a reader then organises those details into significant wholes or gestalts. This kind of prefocussing strategy allows for certain features of situations or characters to be made salient through description or depiction.

In Whee! (McNaughton 2001) and other Preston Pig books, the running joke is at the expense of Mister Wolf and his thwarted attempts to devour Preston. In one scene, a sequence of three illustrations on the one page feature Mister Wolf pertorming one of these attempts. Reader gaze is initially attracted to the central image which frames in close-up the terrified face of Mister Wolf. He is captured in mid-flight and is in a circular frame which is similar to a camera viewtinder. The words: Whee! Crash! Bang! are positioned around the circumference of the frame. This arresting image pushes the gaze outwards to the other two images to determine the function of this image within the conventional left-to-right and top-to-bottom sequence of the fabula. In the top left position on the page, Wolf is shown side-on, speeding down hill on a skateboard with a very determined look on his face. He wears his typical skateboarder fashion-crash helmet, striped bike shorts and top, elbow and kneepads, outwardly giving the appearance of competence. The bottom right image shows
Wolf in a perpendicular and upside down position in a wire rubbish bin, with a tin can having replaced his rider's helmet. The movement of reader gaze back and forth across the three frames tracks simultaneously the action of Wolf and the chronological depiction of the narrative sequence. The narrativity of the picture not only depicts the events chronologically in succession, but also logically in a causal relation. The three-staged event, encoding a shift from competent skateboarder to comic fall guy, can only occur through the semiotic performance of Wolf. And the comic effect can only be explained when this particular mediation is analysed. Hence, the performativity of Wolf, as the focalised object of the reader's vision, evokes memories of other similar slapstick events and through the interplay of reader and text demonstrates the ludic capacities of textual encounters.

While the performative in the above example is located primarily in the visual image, the aggressive acts performed by Wolf and another antagonist, Billy the Bully, are signifiers of these characters' identities. Similarly, the passivity of Preston in this book signifies his apparent victimhood and innocence. It is this easy coupling of act and identity raised earlier that needs to be interrogated. According to Butler, identification is achieved through acts, gestures and enactments which 'are performative in the sense that the essence or identity that they otherwise purport to express are fabrications manufactured and sustained through corporeal signs and other discursive means' $(1990$, p.136). Hence, the aggressive performance of Wolf and Billy involves the deployment of signs (bodily, linguistic, and behavioural) which have already attained meaning within the discourses and practices of 'the social', understood in this narrative as a site of contestation.

The citational and iterative nature of gender performativity is demonstrated in the picture book Prince Charming and Baabarella (Glitz \& Swoboda 2001). The story is essentially a retelling of the romance fairy tale combined with the implied moral dictum that beauty is in the eye of the beholder. The anthropomorphised goats who form the central characters of the story perform gender through the acts, gestures and enactments that Butler suggests. The female goats decorate their bodies with coloured bows, apply vivid green eye shadow, ruby red lipstick and 
mascara, and curl their hair with rollers. While their corporeal style is recognisably feminine, they also discipline their bodies to conform to popular images of the feminine - they diet, pull, pluck, shave and starve their bodies. Their speech and actions take on stereotypical behaviours of jealous, desperate-to-marry-at-all-costs women. However, the performative acts of the goats result in a hyperfemininity, which ultimately parodies the 'original' meanings accorded to gender. Rather than read the text as an uncritical appropriation of sex-role stereotyping, a performative reading provides a space for complicating this view.

Analogous with Butler's (1993) example of the use of drag as a means for complicating the relation between the 'imitation' and the 'original', the goats' hypostatised femininity creates a generalised image of 'woman'; but the 'image' also exposes the distinctness of those aspects of feminine experience which are falsely naturalised as a unitary whole through the regulatory fiction that establishes and sustains the male/female binary. In other words, the goats' camp images of female excess and artifice help undermine and challenge the presumed naturalness of female gender roles and displace the essentialist notion of authentic feminine identity. Consequently, the goats' flamboyance and outrageousness can be seen as powerful tools for a critique of femininity, rather than merely affirmations of stereotypical and oppressive images of women. To take this alternative, perhaps perverted, reading opens out the pleasure of the performative and provides an opportunity for resignification and recontextualisation of the gendered body defying any claims to naturalised or essentialised gender identities. The reader who is on to the joke is provided with an occasion for laughter as the feminised goats reveal the folly of their imitation which is a fabrication that fails to copy an impossible ideal.

Despite this attempt to parody gender identity, the traditional romance frame of the narrative, with its culminating marriage between Prince Charming and Babarella, serves to reinforce for young readers the functioning of social norms and heterosexual identity. Hence, the possibilities for agency that the parody of female representation offers are foreclosed by the fairy tale ending that relies on repetition of an 'act' (marriage) that reinforces identity categories as foundational and "natural'. However, the unnaturalness of goats behaving as humans can also be read as the ultimate display of gender fabrication with its perverted performative effects. Consequently, the text remains open and indeterminate.

When writers and illustrators structure text and illustration in such a way as to elicit an emotional response, readers, in recognising such conditions, may experience a particular bodily response as their attention becomes emotionally charged. For example, in the above examples, they might laugh out loud as they witnesses Wolf's mishap and the goats' ridiculous behaviour. Emotions organise perception to a large degree by employing emotive content and form, and emotional responses are laid down in the early stages of most stories and provide the organisational basis for reader responses to later scenes. For example, the impact of the performative acts (insults and threats) used by Billy the Bully in Whee! is understood in terms of who he is and the context in which the words are stated. Billy's aggressive words, actions, and large bulk (which contrasts with the diminutive childlike body of Preston) work on and through readers, coaxing a particular viewpoint, attitude, or preference.

\section{Reader stance and contextual factors}

$\mathrm{My}$ second question enquires into the ways context affects the stance that one takes in reading. Context refers to the characteristics within the text and the circumstances of its reading as well as the nature of a particular reader. Picture book stories invariably provide information about the self and the social ('I' and the world) and mediate the passage from what the child knows to what she does not know. These characteristics are not exclusive to this genre. However, as the primary audience of picture books is young children, picture books more often than not provide a socialising practice which teachers and parents are keen to endorse. Austin made the notion of sociality prominent in Rule A.1 (1962, p. 14) emphasising that words do things in a social setting. Context is therefore a vital constituent in attempting to understand an utterance's performative force.

On the other hand, unconventional approaches to picture book construction are a key aspect of context. When confronted with a new approach to picture book storying 
or format what might a reader do? One possibility is that a reader may attempt to accommodate the demands of the new approach with her existing mental schemata about narrative, pictorialisation, reading and writing. To theorise this process, we might consider the following processes: the reader scrutinises the text with an eye to isolating the ways it expands upon her previous knowledge of how picture books work; considers how it breaks with tradition yet opens up new possibilities; how it repudiates or amplifies the forms or values of previous picture books; and ultimately how it introduces a new problematic between visual and verbal interaction. While picture books need to reproduce custom, tradition and precedent there is also the opportunity (as in all literary and artistic endeavours) to transform existing paradigms and practices: a point which harks back to Butler's notion of agency.

Further to the textual strategies that trigger particular responses, picture books also work to locate readers in a particular discourse (for example, family, school, gender). Such discursive positioning is a feature of the cultural/ social practice of reading whereby writer, illustrator, and reader are shaped within the social. However, the web of discourses which surrounds the production and reception of picture books, and those discourses which inform their story lines and illustrations encourage a fairly homogenous reading (and writing) community. Consequently, response tends to be ordered around what is viewed as normatively correct. The context in which reading occurs frames to a large extent the reinforcement of these 'normatively correct' values and attitudes. For instance, a picture book shared in the classroom may elicit different responses to one shared among friends in a secret hideaway. The latter context has the potential to subvert any ideological positioning that the text may seek to achieve or any preferred reading a teacher may wish students to take up.

This contrasting example highlights the point that readers are already positioned in a number of discourses and any attempt to achieve a homogenous reading community of consensual response is doomed to fail. It is largely the force of the performative and aesthetic dimensions of a text that prompt a reader to experience the discourse as intensely personal and engaging and produces a particular subjectivity (whether, in Smagorinsky's terms, 'constrained' or 'unbridled') and aesthetic response. The ideological embeddedness of all texts and the ideological frames in which texts are read and shared provide persuasive contexts for interpreting and responding in what could be termed 'proper' or acceptable ways. They also can encourage resistant, subversive or other responses. In picture books, the visual impact of the illustrations, their expressive and arresting form and content are as effective in impacting on the reader's emotional and aesthetic sensitivities and intellectual abilities, as are the vivid imagery, syntactic and semantic content, and figurative elements of the words. Consequently, the stance a reader takes towards the fictional characters or events is prompted by the evocative potential of both words and visuals. Each medium induces a reader to form preferences about how the story should evolve and its outcomes and resolution.

A reader's stance, however, is not solely dependent on the skill of the writer and illustrator as other factors come into play: one's prior positionings, current circumstances, cultural background, emotional make-up, capacity to empathise, and pre-existing disposition to certain values, behaviours, and kinds of humour. The degree to which agency is enacted will depend on those factors impacting on, or inherent in, the reader as well as elements of the text, such as its narrative pull, open/closed structure, and interactive/distancing effects. Consequently, Iser's (1989) suggestion that there is a certain amount of 'indeterminacy' in picture books (and indeed in all literary texts) becomes apparent. Readers, after having taken into account the various perspectives offered by the text, are left with their own resources-experiential, perceptual, cognitive, and aesthetic - to judge what has been communicated and to fill in the gaps of indeterminacy.

Don't step on the crack! (McNaughton 2000) provides a fitting example to demonstrate this gap-filling exercise. Given numerous wamings by the unknown narrator who directly addresses the character and tells him of the dire consequences of stepping on pavement cracks, the final page leaves readers at the point of indeterminacy. After reassuring the boy not to worry and that the chances are that the crack 'might not be in this pavement! It might not even be in this street! It might not even be in this town!', the boy gives a sigh of relief ('Phew!'). The narrator then abruptly 
warns: 'But then again, it might be! So just in case...Don't step on the crack!". The illocutionary and perlocutionary effects of the words and the accompanying illustrations work in double tandem to warn and deter. The final illustration shows the boy frantically moving across the pavement leaping from one space to another desperately trying not to step on a crack. But another leg is seen approaching from around the comer. It is that ultimate perlocutionary step that the boy might take by inadvertently stepping on a crack that provides the suspenseful moment - but one which will not be resolved by the text. Is a collision imminent? Beware!

\section{Fulfilling reader desire}

Finally, I turn to my third question: how the dynamic of desire and reading shapes a reader's response to picture books. It is also a way of returning to many of the points made throughout this paper. While I have suggested that texts work on their readers, readers also work on the texts they encounter. Children, like all readers, give a fictional depth and an imaginative interpretation to picture books that go beyond that which is represented in either the words or the artwork. Illustrations invite child readers to see and believe the fictional proposition that lies before them. Readers, however, are not without agency as they are able to project their own imaginative interpretations and game playing onto what they see. The text, therefore, operates as a mid-way point "between the external world of objects and the reader's own world' (Iser 1989, p.8), or in Smagorinsky's terms, the reading occurs in the 'transactional zone'. The act of reading is therefore a negotiation between this external/internal divide as a reader attempts to read one in terms of the other-the known in relation to the unknown. Thus, reading and viewing are active processes not passive states. In our enthusiasm to have our children or students become successful readers, we may forget to let them negotiate texts on their own terms, to enliven them with their own fictional and imaginative possibilities. We need to be more conscious of children's needs to rest for a while on a picture that interests them or on a word that looks or sounds different-its shape, its font, jts length. Resting, pausing in the narrative moment satisfies a reader's desire for significance, meaning, and perhaps affirmation. Like the dramatic pause of the skilful storyteller, readers need to arrest time momentarily to gaze and to wonder.

Another element that is closely tied to desire is the notion of play. As Iser states: 'Authors play games with readers, and the text is the playground' (1989, p.250). It is also through play that the conjunction between performance and performativity is most apparent. It is the point too where the picture book creators (author, illustrator, designer), readers and texts can be conceived as a dynamic interrelationship that moves towards (but may never reach) the fulfilment of desire. The analogy of the text as playground is one that is becoming evident in many postmodern picture books. In the case of Dear Diary (Fanelli 2000), the textual game subverts meaning as the moment of sense making is continually shifting and being eclipsed by a kaleidoscope of print-play, visual-play, and playful pastiche. The performative element of Dear Diary lies not so much in the use of performative acts and their illocutionary and perlocutionary force, but in the selfconsciously partial rendering of the narrative fragments that dramatise the playful pleasures (jouissance) that come with reading and viewing in an open playground of representation. Changing font size and shape, the intermingling of collage and hand-drawn figures with photographic images, citations from canonical and contemporary poets, visual and verbal punning, visual grammatical, emotive, and spatial codes (which appear in the text as: ! $\left.0^{-}\right)$to give words emphasis and to locate them as part of the print-play form a kalejdoscope of busy colour, print scribbles, incoherence, and metalepsis. In negotiating the demands of the text, a reader takes in words and pictures, scans the pages back and forth, up and down, and criss-crosses their surfaces, effecting an embodied performance. Performative texts such as Dear Diary display their own materiality, drawing attention to what they are and what they aren't. It is in this ironic twist, of invoking the presence of what it isn't (that it is not a conventional picture book) that it paradoxically offers a space of absence that corresponds with the space that lurks in desire and imagination craving fulfilment.

The process of reading picture books takes on a gamelike quality as the reader (and perhaps a mediating adult) 
willingly participate(s) in the narrative encoding of sight and sound. Thereby, there is a consensual, tacit agreement on behalf of a reader to negotiate the boundaries of fantasy through creative interpretation, gap filling, and imaginative engagement. The gamelike elements of a picture book its hidden meanings, latent structures (colour, shape, design) depend on both precedent and tradition. That is, the genre presumes reader knowledge of other picture books and stories. There is also an assumption operating throughout the text that readers engage with texts in particular ways. In some instances, writers and illustrators deliberately work to disrupt any normative reading behaviour and reader expectations of texts through playful strategies of irony and parody and unconventional format/design causing disequilibrium between text and illustration, and between reader and text. This process may in some cases alienate young readers. It may also provide a space for innovation in a reader's interpretation of, and response to, words and images.

While adult readers and some child readers are becoming familiar with the demands of metafictive texts, many children stiil have not encountered them before and may not have the experience to know that these texts are intentionally playful and often ironic. Furthermore, some children might also lack the cultural knowledge and interpretive skills necessary to understand double meaning, intertextuality, inference, and playful textual disruption. The collaborations of Jon Scieszka and Lane Smith have resulted in a number of picture books which are parodic, address readers directly, and blatantly exhibit a selfconsciousness about their own fictive constructedness (see Squids Will Be Squids, 1999: The Stinky Cheese Man and Other Fairly Stupid Tales, 1992). Other picture books employ to varying degrees a postmodernist approach to storytelling. In $l$ will not ever never eat a tomato (Child 2001), the illustrations are a collage of hand drawn cut outs, computer imaging, and patterned paper. The typography, always a visual medium in itself, is particularly playful and evocative as it attempts to bring readers into contact with 'real-life' photo-images as well as imaginative naïve art creations. Furthermore, the language of the text is located in the medium of print-play, and the effect is both material and metaphorical. For instance, when the reluctant vegetable eater, Lola, is depicted eating carrots (or 'orange twiglets from Jupiter') she is shown against a backdrop of outer space; on the left side of one page Lola is in a space ship, and on the other page she shown eating carrots and seated next to a green alien. The text is placed in a wavelike pattern across the page representative of movement across the illustrated backdrop of intergalactic space. In one sense, the written text, with its almost sculptural, visually thythmic and exaggerated formations of letters and words, exceeds wordplay to illustrate the power of representation (that is, the linguistic symbol) to convey both functional and symbolic meanings and to embody a visual, spatial performance.

As the readership of picture books extends, it is never safe to assume a naïve or apprentice reader. As children gradually gain experience of reading picture books, they also develop more refined and sophisticated linguistic, narrative, and visual skills and knowledge. Hence, they are able to detect intertextuality, allusion, parody, and generally become more perceptive to the subtleties of figurative and syntactic features, and iconic representations. Even quite young children are capable of such sophisticated reading behaviour. It would appear that the more demands text and illustration make on readers, the more readers invest in the text.

\section{CONCLUSION}

This paper has applied the concept of the performative from two different philosophical views of language within an overarching framework of reader response. For Austin, the notion of the performative offers a way of attending to what language does as much as to what it says. In literary texts, the performative utterance brings into being characters and their actions. This was illustrated in the examples of Mister Wolf and Billy the Bully (Whee!) where actions and words carried an illocutionary and subsequent perlocutionary force. The performative also brings into being ideas and concepts which these characters and their actions deploy. From this understanding of the performative, we are able to conceive of literature, or in this case picture books, as the representation of a series of acts or events that employs active language that produces the things it names. For Butler, the performative provides a way of thinking about social acts which call attention to the nature of identity and how it is produced or generated, the ways 
social norms are enacted and given legitimacy, and the tension that exists between agency, desire and social change. These elements were considered in the performance of femininity and heterosexual identity in Prince Charming and Baabarella.

The process of iteration paradoxically is both the meeting and departure point for Austin and Butler in their theorising of the performative. While Austin's theory relies on the way the repetition of the performative in a single occasion makes something happen, Butler is concerned with the way the habitual repetition of the performance produces historical and social realities and meanings (for example, one becomes a man or a woman). In broader, generic terms, this point of difference is central to the construction and reception of picture books, where there are two ways of thinking of these texts as performative. In an Austinian sense, picture books, through words and visuals, accomplish a specific act which imaginatively proposes a 'reality' within its narrative frame, and its language and visuals do something in that frame. On the other hand, a Butlerian view would see the success of the picture book form as a literary event that repeatedly takes up norms and conventions, but which may also subvert those norms and conventions as in the case of metafictive texts such as / will not evernever eat a tomato or in the playful indeterminacy offered in Don't step on the crack!. Therefore, the picture book offers a means for considering aspects of its literary and aesthetic construction as well as its social and cultural significance.

Ultimately, picture books are designed to set up a desire for a particular kind of reading whether it is shared, performative, interactive, pleasurable, or contemplative. In their developing experience with reading, young children learn that picture books: offer particular kinds of delight (response); activate desire (they are both positioned to desire and to have their desires satisfied); operate within 'an horizon of expectation' (Jauss 1982). Quite simply and ideally, as the child engages with picture books she gains pleasure as she encounters a story conveyed with skill through words and visuals. It is ultimately this particular kind of pleasure derived from a narrative experience conveyed with succinctness and through a dual discourse of communication that distinguishes picture books from other discourses and justifies our continued interest and interrogation.

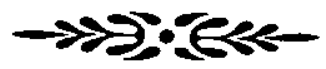

\section{ACKNOWLEDGEMENTS}

I would like to acknowledge the support and advice offered by Rod McGillis during the final revision of this paper. Also, thanks to John Stephens for pointing me in the direction of some useful articles, and to Wendy Morgan for her contributions when this paper was just an idea.

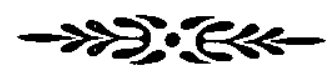

\section{REFERENCES}

Allen, J. (1996) Fowl Play. London, Orion Children's Books.

Allen, P. (1998) Mr McGee and the Biting Flea. Ringwood, Puffin.

Austin, J.L. (1962) How to Do Things With Words. Cambridge, Harvard University Press.

Butler, J. (1990) Gender Trouble: Feminism and the Subversion of Identity. London, Routledge.

(1993) Bodies That Matter: On the Discursive Limits of "Sex". New York, Routledge.

Child, L. (2001) I Will Not Ever Never Eat a Tomato. London, Orchard Books.

Culler, J. (1997) Literary Theory: A Very Short Introduction. Oxford, Oxford University Press.

. (2000) 'Philosophy and Literature: The fortunes of the performative'. Poetics Today, 21, 3: 503-519.

Fanelli, S. (2000) Dear Diary. London, Walker Books. 
Glitz, A. \& Swoboda, A. (2001) Prince Charming and Baabarella. London, Cat's Whiskers.

Iser, W. (1978) The Act of Reading: A Theory of Aesthetic Response. Baltimore, MD, Johns Hopkins University Press.

(1989) Prospecting: From Reader Response to Literary Anthropology. Baltimore and London, Johns Hopkins University Press.

Jauss, H. R. (1982) Towards an Aesthetic of Reception. Trans. Timothy Bahti. Minneapolis, University of Minnesota Press.

Kress, G. (1997) 'Visual and verbal modes of representation in electronically mediated communication: the potentials of new forms of text', in I. Synder (ed) Page to Screen: Taking Literacy into the Electronic Age. St Leonards, Allen \& Unwin, pp. 53-79.

McNaughton, C. (2000) Don't Step on the Crack! London, HarperCollins.

\section{HarperCollins.}

(2001) Whee! London,

Parker, A. \& Sedgwick, E. Kosofsky (1995)

'Introduction: Performativity and performance', in A. Parker and E. Sedgwick Kosofsky (eds) Performativity and

Performance. London, Routledge, pp. 1-18.

Petrey, S. (1990) Speech Acts and Literary Theory. London, Routledge.

Rosenblatt, L. (1985) 'The transactional theory of the literary work: Implications for research', in C. Cooper (ed) Reseakching Response to Literature and the Teaching of Literature: Points of Departure, Norwood, NJ, Ablex, pp.33-53.

Scieszka, J. \& Smith, L. (1999) Squids Will Be Squids. London, Puffin.
(1992) The Stinky Cheese

Man and Other Fairly Stupid Tales. New

York, Penguin.

Smagorinsky, P. (2001) 'If meaning is constructed, what is it made from?' Toward a cultural theory of reading'. Review of Educational Research, 71, 1: 133-169.

Stephens, J. (1992) Language and ldeology in Children's Fiction. London \& New York, Longman

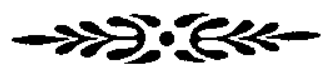

\section{BIOGRAPHICAL NOTE}

Kerry Mallan teaches courses in children's literature, storytelling, and school librarianship at Queensiand University of Technology. Her research interests include picture books, film, and children's literature. She is the coeditor (with Sharyn Pearce) of a forthcoming book entitled Youth Cultures: Texts, Images and Identities (Greenwood). 